DOI:10.17951/bc.2021.6.49-61

\begin{tabular}{lcr}
\hline & ANNALES \\
& UNIVERSITATIS MARIAE CURIE-SKŁODOWSKA & \\
LUBLIN - POLONIA & \\
VOL.VI & SECTIO M & 2021 \\
\hline
\end{tabular}

\title{
Tadeusz Zienkiewicz
}

Jan Kochanowski University of Kielce, Kielce, Poland

tzienkiewicz@op.pl

ORCID: https://orcid.org/ 0000-0002-6941-6309

Ewa Zienkiewicz

Medical University of Lublin, Lublin, Poland.

evazien@op.pl

ORCID: https://orcid.org/0000-0002-1430-3358

\section{Socio-economic status as a determinant of access to paediatric health care in Poland}

\section{Introduction}

The problem of inequalities of access to healthcare is the subject of many studies and analyses. Indeed, because of its complexity, researchers break its analysis into individual social, economic, urban, cultural, racial and demographic factors ${ }^{1,}{ }^{2}$. For each of the states of the World, the challenge is to create a system that guarantees equal access to medical services for its residents. Ongoing research takes into account a number of factors contributing to the fact that patients of low socio-economic status (SES) do not fully benefit from health care. There is evidence that such individuals receive fewer diagnostic tests and

1 W.J. Riley, Health Disparities: Gaps in Access, Quality and Affordability of Medical Care, “Trans Am Clin Climatol Assoc." 2012, vol. 123, pp. 167-174,

2 R. Coocson, C. Propper, M. Asaria, R. Raine, Socio-Economic Inequalities in Health Care in England. "Fiscal studies" 2016, vol. 37(3-4), pp. 371-403, https://doi.org/10.1111 /j.1475-5890.2016.12109 
medications for many chronic diseases ${ }^{3},{ }^{4}$, and have limited access to health care due to cost and coverage ${ }^{5}$. Moreover, patients with low SES are less likely to be perceived as responsible, independent, or rational ${ }^{6}, 7$, which often influences physicians' clinical decisions ${ }^{8}$.

It is believed that tailoring care options to a patient's socio-economic situation can improve adherence and thus improve health outcomes ${ }^{9}$. Yet, the same studies have shown that physicians hold that financial and insurance coverage constraints faced by low SES patients limit access to care and result in poorer health outcomes for these patients. Research also indicates a lack of interest in some physicians in caring for low SES patients. The reason for this is publicly funded health insurance and this means low reimbursement rates ${ }^{10},{ }^{11}$.

Difficulties with access to healthcare in Poland, especially access to specialist physicians, have been widely recorded ${ }^{12},{ }^{13}$. Moreover, demographic, economic and social changes taking place in Polish society have resulted in an increased

3 L.X. Clegg, M.E. Reichman, B.A. Miller, et al. Impact of socioeconomic status on cancer incidence and stage at diagnosis: selected findings from the surveillance, epidemiology, and end results: National Longitudinal Mortality Study. "Cancer Causes Control” 2009; vol. 20, pp. 417435, https:// doi: 10.1007/s10552-008-9256-0.

4 C.C. Hsu, C.H. Lee, M.L. Wahlqvist, et al. Poverty increases type 2 diabetes incidence and inequality of care despite universal health coverage, "Diabetes Care" 2012, vol. 35, pp. 2286-2292, https://doi: 10.2337/dc11-2052

5 Washington Health Alliance. Disparities in Care 2014 Report. Seattle, WA: Washington Health Alliance.

6 M. van Ryn, J. Burke, The effect of patient race and socioeconomic status on physicians' perceptions of patients, “SocSci Med." 2000, vol. 50, pp. 813-828, https://doi.org/10.1016/S02779536(99)00338-X

7 D.S. Meyers, R. Mishori, J. McCann, et al. Primary care physicians' perceptions of the effect of insurance status on clinical decision making. "Ann Fam Med." 2006, vol. 4, pp. 399-402, https:// 10.1370/afm.574

8 S.M. Bernheim, J.S. Ross, H.M. Krumholz, E.H. Bradley. Influence of patients' socioeconomic status on clinical management decisions: a qualitative study. "Ann Fam Med." 2008, vol. 6, pp. 53-59, https:// 10.1370/afm.749

9 M.K. Wynia, J.B. VanGeest, D.S. Cummins, I.B. Wilson. Do physicians not offer useful services because of coverage restrictions? "Health Aff (Millwood)." 2003, vol. 22, pp. 190-197, https:// 10.1377/hlthaff.22.4.190

${ }^{10}$ E. Hing, S.L. Decker, E. Jamoom, Acceptance of New Patients With Public and Private Insurance by Office-Based Physicians: United States, 2013. “NCHS Data Brief” 2015, vol. 195, pp. 1-8.

${ }^{11}$ S.L. Decker, Medicaid physician fees and the quality of medical care of Medicaid patients in the USA. "Rev Econ Househ." 2007, vol. 5, pp. 95-112.

12 P. Baliński, R. Krajewski. Lekarze i lekarze dentyści w Polsce - charakterystyka demograficzna. Stan w dniu 31.12.2017r. Warszawa: NIL; 2018.

13 A. Domagała A, K. Dubas-Jakóbczyk. Migration intentions among physicians working in Polish hospitals - Insights from survey research. "Health Policy"2019, vol. 8, pp. 782-789, https:// 10.1016/j.healthpol.2019.06.008 
demand for medical services. The pro-family policy implemented by the government, including the "Family 500+" programme adopted in 2016, is likely to contribute to an increase in the birth rate and thus an increase in demand on the medical services market ${ }^{14}$. The supply of medical services, which is closely related to the number of paediatricians, may, hence, become a problem.

In 2019, the number of doctors in Poland ranged from less than 2.5 per 1,000 inhabitants, compared to 5.3 in Austria and 3.0 in the Untied Kingdom ${ }^{15}$. The rate of paediatricians per 100,000 inhabitants aged under 17 in Poland (80), also falls more than $18 \%$ below the EU average (98) and their average age was 55.8 years, with a median of 56.0 years. The percentage of paediatricians below 50.0 years of age was $34.5 \%{ }^{16}$. The problem of generational change is very serious because the average annual number of new specialists in paediatrics is only 240 and the retirement age for women is 60.0 years old and for men 65.0.

Paediatricians have always been an underestimated group in medical care in Poland. Shortages of paediatricians are noticeable both in the regions and in large provincial centres. In addition, paediatric wards are being closed down or their activities curtailed because of their low profitability ${ }^{17}$. This is primarily due to inaccurate pricing of paediatric procedures. Higher salaries in small towns for paediatricians result from higher rates offered by local employers, who do so at the expense of the indebtedness of the medical entities they manage. The earnings of paediatricians on full-time posts in specialist hospitals are lower than those of residents. This poses a real threat that, with such a large generation gap, there will eventually be a shortage of people who are prepared to make quite large sacrifices working in specialist paediatric hospitals ${ }^{18}$. Moreover, the systems and rules for gaining specialisation in Poland are not simple. They change over time and there are many barriers, including difficulties in finding places in which to specialise, the privatisation of outpatient healthcare, changes in the form of employment, the lack of employment contracts and the changing rules of contracting by the National Health Fund.

${ }^{14}$ Sejm RP. Ustawa z dnia 11 lutego 2016 r. o pomocy państwa w wychowywaniu dzieci. Dz.U. 2016 poz. 195. 2016.

15 OECD. Health at a Glance 2021: OECD Indicators, OECD Publishing, Paris, 2021, https://doi.org/10.1787/ae3016b9-en.

${ }^{16}$ P. Baliński, R. Krajewski. Lekarze i lekarze dentyści w Polsce - charakterystyka demograficzna. Stan w dniu 31.12.2017r. Warszawa: NIL; 2018.

17 The website of Puls Medycyny, https://pulsmedycyny.pl/polska-ma-najmniej-lekarzy-wcalej-unii-europejskiej-977230

18 The website of Mp. pl, Dla pacjentów, https://www.mp. pl/pacjent/pediatria/aktualnosci/ badania/183022,dola-pediatry 
The above examples and other factors, such as the emigration of young doctors ${ }^{19}$, have contributed to a reduction in the number of specialised physicians in many areas. As such, it is difficult to envisage a noticeable increase in the number of specialists in Poland. Furthermore, the problem of accessing paediatric healthcare services and the burden placed on paediatricians is gaining importance. The unequal spatial distribution of physicians is not only a problem in Poland. Similar issues have been encountered in all parts of the world ${ }^{20},{ }^{21}$.

In the light of the above, the problem of unequal access to public paediatric healthcare is a complex one. Therefore, it seemed reasonable to the authors to undertake research to clarify the determinants of this undesirable phenomenon, with a focus on the socio-economic status of patients. Clarifying this problem will also provide an answer to whether socio-economic status can be a discriminatory factor in terms of both the availability and quality of medical services.

The work presented here attempts to determine whether the socio-economic status of patients affects the spatial diversity of access to paediatric healthcare in Poland. The authors hypothesize that:

(a) patients of higher socio-economic status use public health services to a lesser extent

b) paediatricians working in economically underdeveloped areas are more burdened with work than their colleagues from highly developed areas.

The method of principal component analysis was used to carry out the research process. The study covered the period 2010-2017 due to this being the source of the only reliable data at the time of preparing the paper.

\section{Research and results}

The highest administrative level in Poland, the voivodeship (NUTS-2), was used as the unit of analysis and is hereinafter referred to as "province". A principal component analysis was performed on the standardised attributive variables of each province. The database of Statistics Poland (GUS) was

19 A. Murdoch. Emigracja lekarzy z Polski. Warszawa: SGH; 2011.

${ }^{20}$ F. Tille, B. Gibis, K. Balke, A. Kuhlmey, S. Schnitzer. Sociodemographic and health-related determinants of health care utilisation and access to primary and specialist care: Results of a nationwide population survey in Germany (2006-2016). "Z Evid Fortbild Qual Gesundhwes” 2017, vol. 126, pp. 52-65, https:// 10.1016/j.zefq.2017.07.012

${ }^{21}$ K.E. Lasser, D.U. Himmelstein, S. Woolhandler. Access to Care, Health Status, and Health Disparities in the United States and Canada: Results of a Cross-National Population-Based Survey. "Am J Public Health" 2006, vol. 96(7), pp. 1300-1307, https://10.2105/AJPH.2004.059402 
the source of statistical data of the number of paediatricians (2010-2017), the number of hospital beds (2010-2017), the population under 17 years of age (2010 and 2017), the index of urbanisation and the disposable income per capita. The number of patients treated per paediatrician (PTP) was calculated by dividing the number of patients treated in paediatric wards (including interward movement) in 2017, by the population of paediatricians. The population density of people aged under 17 years of age was calculated as the ratio of the size of this population to the area of the province in which they live ${ }^{22}$. The attributive variables were: population density (2010), population density below 17 years of age (2010), the rate of population increase for those under 17 years of age (2010 to 2017), the number of paediatric hospital beds per 10,000 residents below 17 years old (2010), the disposable income per capita (2010), the paediatrician workforce per 100,000 residents under 17 years of age and GDP per capita (2010). The data set consisted of a matrix of $16 \times 7$, where the rows represented the sixteen provinces and the columns represented the seven standardised attributive variables.

By entering the exploratory factor analysis, eigenvalues were identified which was helpful in deciding the number of principal factors. Eigenvalues higher than 0.7 were adopted to explain the projection of the samples on the factor plane after a Varimax rotation. The factor model (the number of principal components) was determined using principal component analysis. The review of the results began with an assessment of eigenvalues.

Multiple linear regression analysis was employed to identify factors associated with the number of patients treated in paediatric wards per paediatrician in 2017. The number of patients treated in paediatric wards per paediatrician was chosen as the dependent variable. The principal component scores, determined by principal component analysis, were chosen as explanatory variables in the multiple regression analysis. All analyses were performed using Statistica software, and the statistical significance level was set at 5\%.

The criterion for the Cattell's scree test was chosen to assess the choice of factors for further analysis. According to the Cattell's scree test, two factors should be selected to explain $89.5 \%$ of the total variability. On this basis, a two-factor structure was selected, which was analysed using the main component method.

First, a list of descriptive statistics of attributive variables was identified (Table 1).

22 GUS. Knowledges databases. 2019. Available at: http://swaid.stat.gov.pl/SitePages/ StronaGlownaDBW.aspx. Accessed June 29, 2019. 
Table 1 Descriptive statistics ( $\mathrm{N}=16$ provinces).

\begin{tabular}{|l|r|r|r|r|}
\hline Variables & \multicolumn{1}{|l|}{ Mean } & $\begin{array}{l}\text { Standard } \\
\text { deviation }\end{array}$ & Minimum & Maximum \\
\hline Population density [person/ $\mathrm{km}^{2}$ ] & 129.94 & 74.42 & 60.00 & 376.00 \\
\hline $\begin{array}{l}\text { Density of population under 17 years old } \\
\text { [person/km2] }\end{array}$ & 24.19 & 12.95 & 11.27 & 64.81 \\
\hline Increase rate of population 0-17 [\%] & -6.04 & 3.99 & -11.47 & 3.05 \\
\hline Disposable income per capita [PLN] & 1150 & 145 & 907 & 1602 \\
\hline GDP per capita [PLN] & 34160 & 8185 & 25875 & 59666 \\
\hline $\begin{array}{l}\text { Paediatrician workforce per 100,000 } \\
\text { residents under 17 years of age }\end{array}$ & 43.95 & 9.06 & 29.65 & 70.43 \\
\hline $\begin{array}{l}\text { Number of hospital beds per 10,000 resi- } \\
\text { dents of 0-17 years of age }\end{array}$ & 15.94 & 2.79 & 11.47 & 22.13 \\
\hline No of patients treated per paediatrician & 157.08 & 40.33 & 87.15 & 224.67 \\
\hline
\end{tabular}

Note: own elaboration

The first principal component presented a positive high load factor with regard to: disposable income per capita, GDP per capita, increase rate of population of $0-17$ years old and paediatrician workforce per 100,000 residents under 17 years of age. The first two factors of the first principal component are related to economic status. The other two factors correspond with the social development of the provinces. Thus, the first principal component can be interpreted as representing the level of socio-economic status of the provinces.

The population density and density of population under 17 years of age can be treated as the degree of urbanisation determining index. In this study, the second main component contained such a high percentage of both indices that it could be interpreted as determining the degree of urbanisation (Table 2).

Table 2. Factor loadings after a Varimax rotation.

\begin{tabular}{|l|c|c|}
\hline Variable & $\begin{array}{l}\text { First principal } \\
\text { component }\end{array}$ & $\begin{array}{l}\text { Second principal } \\
\text { component }\end{array}$ \\
\hline Population density [person $\left./ \mathrm{km}^{2}\right]$ & 0.218 & 0.932 \\
\hline Density of population under 17 years old [person $/ \mathrm{km}^{2}$ ] & 0.238 & 0.907 \\
\hline Number of hospital beds per 10,000 residents [pcs] & -0.262 & 0.662 \\
\hline $\begin{array}{l}\text { Paediatrician workforce per } 100,000 \text { residents under } \\
17 \text { years of age [person] }\end{array}$ & 0.701 & 0.629 \\
\hline
\end{tabular}




\begin{tabular}{|l|r|r|}
\hline GDP per capita [PLN] & 0.925 & 0.255 \\
\hline Increase rate of population 0 - 17 in 2010 - 2017 [\%] & 0.938 & 0.183 \\
\hline Disposable income per capita [PLN] & 0.939 & -0.005 \\
\hline
\end{tabular}

Note: own elaboration

The multiple regression analysis indicated that the first principal component scores displayed a statistically significant negative correlation with the dependent variable (the number of treated patients per paediatrician on public paediatric wards). Considering this finding, the socio-economic status negatively correlates with the number of treated patients per paediatrician in public paediatric wards.

The second principal component scores showed a statistically insignificant positive correlation with the dependent variable (Table 3).

Table 3. Multiple regression analysis results.

\begin{tabular}{|l|l|l|l|}
\hline Explanatory variable & $\beta$ coefficient & Standard error & $\mathrm{p}$ value \\
\hline Constant & 140.308 & 8.583 & $\mathrm{p}<0.000$ \\
\hline First principal component & -26.845 & 8.864 & 0.010 \\
\hline Second principal component & 3.946 & 8.864 & 0.664 \\
\hline
\end{tabular}

Note: own elaboration.; $\mathrm{R}^{2}=0.412 ; \mathrm{F}=0.029$

\section{Discussion}

We identified two independent principal components describing the dependent variable: the level of socio-economic status and the level of urbanisation. Statistical significance was noted in only the case of the level of socio-economic status.

An analysis of the socio-economic status indicates that an increase in this component is accompanied by a decrease in the output of paediatric services per paediatrician. Therefore, it can be concluded that the number of paediatricians in economically well-developed areas is higher than in economically under-developed areas. Multiple regression analysis suggests that the higher the socio-economic status of the patient, and the economic status of the patient's parents, the less readiness there is to use public paediatric healthcare. Thus, a public paediatric workforce in areas with high economic status might be less burdened. In economically less developed areas, the demand placed upon paediatricians in public healthcare centres could be greater. 
People living in under-developed regions are usually more socially disadvantaged and so tend to require greater access to healthcare. They use more acute hospital care and less primary care or private medical service than patients with a higher socio-economic status ${ }^{23},{ }^{24}$.

Patients look for factors described by Thomas and Penchansky such as accessibility, accommodation, acceptability and competence in clinical care ${ }^{25},{ }^{26}$. Hospital care in Poland is perceived as more specialised and cheaper than outpatient care. Outpatient care does not guarantee such a wide spectrum of free diagnostic tests as provided by a hospital. This results in additional time and expense for the check-ups recommended by the general practitioner (GP). Moreover, while the population under the age of 18 in Poland benefits from being able to access the healthcare system free of charge, a GP is only allowed to prescribe a closed catalogue of necessary check-ups free of charge. More advanced follow-ups and diagnostic tests (e.g. magnetic resonance imaging, computed tomography) require the patient to pay. In addition to the above, outpatient care is commonly recognised as less accessible than hospital care, especially in underdeveloped areas where road network density is low and public transport unreliable.

Most of the citizens living in under-developed provinces, with a low level of income, cannot afford regular outpatient appointments because of the time involved and, in particular, the fees for diagnostic tests. Patients do not want to waste time searching for a specialist. They expect the specialist to care for them. A stay in a hospital guarantees such a service. Considering accessibility, hospital-based care is more convenient than an outpatient one. In addition, parents of small children usually work during regular office hours - which makes it challenging to access outpatient services during that time. The hospital relieves them of this problem. And besides, they are allowed to claim payable sick leave for the duration of the child's stay in hospital.

Finally, the adoption of the new „Act on Publicly Funded Health and Personal Healthcare Services" and the reform of the Night and Holiday Medical Care, has led to contact points being located in hospitals, often in emergency depart-

${ }_{23}$ R. Coocson, C. Propper, M. Asaria, R. Raine, Socio-Economic Inequalities in Health Care in England. "Fiscal studies" 2016, vol. 37(3-4), pp. 371-403, https://doi.org/10.1111 /j.1475-5890.2016.12109

${ }^{24}$ S. Kangovi, F.K. Barg, T. Carter, J.A. Long, R. Shannon, D. Grande. Understanding Why Patients Of Low Socioeconomic Status Prefer Hospitals Over Ambulatory Care. "Health Affairs" 2013, vol. 32(7), pp. 1196-1203, https:// doi:10.1377/hlthaff.2012.0825

25 R. Penchansky, J.W. Thomas. The concept of access: definition and relationship to consumer satisfaction. "Med Care” 1981, vol. 19(2), pp. 127-140.

${ }^{26}$ J.W. Thomas, R. Penchansky. Relating satisfaction with access to utilization of services. “Med Care" 1984, vol. 22(6), pp. 553-568. 
ments ${ }^{27}$. This has contributed to an increased number of hospitalised patients. The previous system emphasised substitution treatment by the general practitioner, who only in very demanding cases referred the patient to hospital. The new system creates a situation where the patient is, for all intents and purposes, already in hospital. In addition to the above, there are many insurance companies active in economically developed areas, guaranteeing round-the-clock medical care for a small monthly fee. In less developed regions, not attractive for medical business, the population is very poorly served by private medical services - including paediatric ones.

Populations living in under-developed regions, with lower disposable income per capita, mostly use public healthcare because of a lack of alternative means. Physicians in economically well-developed regions spend more of their working time in private clinics or outpatient care facilities than in public healthcare units, even though the latter are usually their primary place of work. The combination of economic, social and organisational factors creates a specific social norm regarding the acceptability of hospital versus outpatient care. A hospital is viewed as the place to go to when one is sick, but primarily because medical check-ups are provided free of charge.

The presented analysis reveals that areas with a high level of disposable income per capita are characterised by better access to the paediatric services. This situation is also related to the fact that there is a network of medical schools, including universities, in most principal cities of provinces with a high level of socio-economic development. The high supply of medical services contributes to a more efficient use of medical staff in these provinces than in areas without medical education establishments. The existence of better medical care in regions with a high level of socio-economic development is an indisputable fact ${ }^{28}$.

The research presented in this paper, referring specifically to Poland, builds upon our basic understanding of the subject ${ }^{29},{ }^{30}$, and helps to fill a gap in the existing literature.

${ }^{27}$ Sejm RP. Ustawa z dnia 27 sierpnia 2004 r. o świadczeniach opieki zdrowotnej finansowanych ze środków publicznych. Dz.U. 2018 poz. 151. 2004.

${ }_{28}$ P. W. Newacheck, Y.Y. Hung, M.J. Park, C.D. Brindis, C.E. Irwin. Disparitities in adolescent health and health care: Does socioeconomic status matter? "Health Services Research" 2003, vol. 38(5), pp. 1235-1252, https:// doi:10.1111/1475-6773.00174

${ }^{29}$ E. Zienkiewicz, T. Zienkiewicz, S. Dziaduch. Regional differences in access to health care in Poland from the perspective of health care resources. "Annals of Agricultural and Environmental Medicine" 2018, vol. 1, pp. 77-81.

30 A. Domagała, K. Dubas-Jakóbczyk. Migration intentions among physicians working in Polish hospitals - Insights from survey research. "Health Policy" 2019, vol. 8, pp. 782-789. 


\section{Conclusions}

This article focuses on the socioeconomic status of patients in the context of their equal access to paediatric health care resources. It is explained that in Poland, public paediatric health care is mostly used by people with low SES. This state of affairs brings about a situation wherein in low-income areas, the workload of paediatricians is much higher than in high-income areas. In addition, the ageing of the paediatric workforce contributes to a growing crisis in the supply of paediatric services. Regional disparities in allocation and unequal workloads of paediatricians can be a significant barrier or even completely exclude part of the young population from access to the health care system.

The results suggest that a low level of socioeconomic development may be one of the factors causing high demand for public paediatric healthcare, thereby increasing the workload of paediatricians and posing a threat to the quality of healthcare services in underdeveloped provinces. The public paediatric workforce with the highest workload is seen in economically underdeveloped provinces with the lowest disposable income. Well-developed provinces attract paediatricians, and the population benefits from easier access to paediatric healthcare. The elimination of inequalities in access to the healthcare system is an important element in a country's healthcare policy. The research presented in this paper can contribute to the formulation of a healthcare policy to negate the factors that induce an unequal distribution of paediatricians and to ensure equal access to healthcare for children and adolescents.

Conducting additional research, covering other types of factors, including social, cultural and infrastructural, would broaden our knowledge about their impact on patients' accessibility to a particular healthcare sector in Poland.

Bibliography

\section{Sources}

- Sejm of the Republic of Poland. Act of 27 August 2004 on health care services financed from public funds. Dz.U. 2018, item 151. 2004.

- Sejm RP. Act of 11 February 2016 on state aid in child rearing. Dz.U. 2016 item 195. 2016.

\section{Literature}

- Baliński P. , Krajewski R. Lekarze i lekarze dentyści w Polsce - charakterystyka demograficzna. Stan w dniu 31.12.2017r. Warszawa: NIL; 2018. 
- Bernheim S.M., Ross J.S., Krumholz H.M., Bradley E.H. Influence of patients' socioeconomic status on clinical management decisions: a qualitative study. "Ann Fam Med." 2008, vol. 6, pp. 53-59, DOI: https:// 10.1370/afm.749

- Clegg L.X., Reichman M.E., Miller B.A., et al. Impact of socioeconomic status on cancer incidence and stage at diagnosis: selected findings from the surveillance, epidemiology, and end results: National Longitudinal Mortality Study. "Cancer Causes Control" 2009; vol. 20, pp. 417-435, DOI: https:// doi: 10.1007/s10552-008-9256-0.

- Coocson, R., Propper, C., Asaria, M., Raine, R. Socio-Economic Inequalities in Health Care in England. "Fiscal studies" 2016, vol. 37(3-4), pp. 371-403, DOI: https://doi. org/10.1111/j.1475-5890.2016.12109

- Decker S.L. Medicaid physician fees and the quality of medical care of Medicaid patients in the USA. "Rev Econ Househ." 2007, vol. 5, pp. 95-112.

- Domagała A., Dubas-Jakóbczyk K. Migration intentions among physicians working in Polish hospitals - Insights from survey research. "Health Policy" 2019, vol. 8, pp. 782-789.

- GUS. Knowledges databases. 2019. Available at: http://swaid.stat.gov.pl/SitePages/ StronaGlownaDBW.aspx. Accessed June 29, 2019.

- Hing E., Decker S.L., Jamoom E. Acceptance of New Patients With Public and Private Insurance by Office-Based Physicians: United States, 2013. "NCHS Data Brief" 2015, vol. 195, pp. 1-8.

- Hsu C.C., Lee C.H., Wahlqvist M.L., et al. Poverty increases type 2 diabetes incidence and inequality of care despite universal health coverage. "Diabetes Care" 2012, vol. 35, pp. 2286-2292, DOI: https://doi: 10.2337/dc11-2052

- Kangovi S., Barg F.K., Carter T., Long J.A., Shannon R., Grande D. Understanding Why Patients Of Low Socioeconomic Status Prefer Hospitals Over Ambulatory Care. "Health Affairs" 2013, vol. 32(7), pp. 1196-1203, DOI: https://doi:10.1377/ hlthaff.2012.0825

- Lasser K.E., Himmelstein D.U, Woolhandler S. Access to Care, Health Status, and Health Disparities in the United States and Canada: Results of a Cross-National Population-Based Survey. "Am J Public Health" 2006, vol. 96(7), pp. 1300-1307, DOI: https://10.2105/AJPH.2004.059402

- Meyers D.S., Mishori R., McCann J., et al. Primary care physicians' perceptions of the effect of insurance status on clinical decision making. "Ann Fam Med." 2006, vol. 4, pp. 399-402, DOI: https:// 10.1370/afm.574

- Murdoch A. Emigracja lekarzy z Polski. Warszawa: SGH; 2011.

- Newacheck P. W., Hung Y.Y., Park M.J., Brindis C.D., Irwin C.E. Disparitities in adolescent health and health care: Does socioeconomic status matter? "Health Services Research" 2003, vol.38(5), pp. 1235-1252, DOI: https:// doi:10.1111/1475-6773.00174

- OECD. Health at a Glance 2021: OECD Indicators, OECD Publishing, Paris, 2021, DOI: https://doi.org/10.1787/ae3016b9-en.

- Penchansky R., Thomas J.W. The concept of access: definition and relationship to consumer satisfaction. "Med Care” 1981, vol. 19(2), pp. 127-140.

- Riley W.J., Health Disparities: Gaps in Access, Quality and Affordability of Medical Care, “Trans Am Clin Climatol Assoc." 2012, vol. 123, pp. 167-174,

- The website of Mp. pl, Dla pacjentów, https://www.mp. pl/pacjent/pediatria/aktualnosci/badania/183022,dola-pediatry 
- The website of Puls Medycyny, https://pulsmedycyny.pl/polska-ma-najmniej-lekarzyw-calej-unii-europejskiej-977230

- Thomas, J.W., Penchansky, R. Relating satisfaction with access to utilization of services. "Med Care" 1984, vol. 22(6), pp. 553-568.

- Tille F., Gibis B., Balke K., Kuhlmey A., Schnitzer S. Sociodemographic and healthrelated determinants of health care utilisation and access to primary and specialist care: Results of a nationwide population survey in Germany (2006-2016). "Z Evid Fortbild Qual Gesundhwes" 2017, vol. 126, pp. 52-65, DOI: https:// 10.1016/j. zefq.2017.07.012

- van Ryn M., Burke J. The effect of patient race and socioeconomic status on physicians' perceptions of patients, "SocSci Med." 2000, vol. 50, pp. 813-828, DOI: https://doi. org/10.1016/S0277-9536(99)00338-X

- Washington Health Alliance. Disparities in Care 2014 Report. Seattle, WA: Washington Health Alliance.

- Wynia M.K., VanGeest J.B., Cummins D.S., Wilson I.B. Do physicians not offer useful services because of coverage restrictions? "Health Aff (Millwood)." 2003, vol. 22, pp. 190-197, DOI: https:// 10.1377/hlthaff.22.4.190

- Zienkiewicz E., Zienkiewicz T., Dziaduch S. Regional differences in access to health care in Poland from the perspective of health care resources. "Annals of Agricultural and Environmental Medicine" 2018, vol. 1, pp. 77-81. DOI: https://doi. org/10.5604/12321966.1235169

Summary: Background: The work presented here attempts to determine whether patients' socioeconomic status affect the spatial diversity of access to paediatric healthcare in Poland. Hence, the aim of this study was to identify the main factors that determine differences in the distribution and workload of paediatricians in Poland. In particular, to clarify the role of patients' socio-economic status in access to public paediatric health care. This research, specific to conditions in Poland, will contribute to the further development of knowledge in this field. Data were obtained from the Statistics Poland database. Principal component analysis of standardized attribute variables related to provinces and multivariate regression were employed to identify factors of differences in paediatrician workload. Results: Two principal components were identified. The first, the level of socio-economic status is negatively correlated with the number of treated patients per paediatrician $(-26.845, \mathrm{p}=0.010)$. The second, the degree of urbanisation, presents a statistically insignificant positive correlation with the mentioned patients' number $(3.946, p=0.664)$. Conclusions: The research suggests that socio-economic factors may affect the uneven spatial distribution of the workload of paediatricians in Poland and cause differences between the provinces in the equal access to paediatricians. This research may thus provide implications for policy and practice, as well as lead to a better understanding of the problem.

Keywords: socio-economic status; urbanisation; paediatricians; healthcare access; regional diversity 


\section{Status społeczno-ekonomiczny jako determinanta dostępu do pediatrycznej opieki zdrowotnej w Polsce}

Streszczenie: W prezentowanej pracy podjęto próbę określenia, czy status społeczno-ekonomiczny pacjentów wpływa na przestrzenne zróżnicowanie dostępu do pediatrycznej opieki zdrowotnej w Polsce. Dlatego też celem pracy była identyfikacja głównych czynników determinujących różnice w rozmieszczeniu i obciążeniu pracą lekarzy pediatrów w Polsce. W szczególności, wyjaśnienie roli statusu społeczno-ekonomicznego pacjentów w dostępie do publicznej pediatrycznej opieki zdrowotnej. Badanie to, specyficzne dla warunków polskich, przyczyni się do dalszego rozwoju wiedzy w tej dziedzinie.. Dane uzyskano z bazy danych Głównego Urzędu Statystycznego. W celu identyfikacji czynników różnic w obciążeniu pracą pediatrów zastosowano analizę składowych głównych standaryzowanych zmiennych czynnikowych dotyczących województw oraz regresję wieloraką. Wyniki: Zidentyfikowano dwie składowe główne. Pierwsza z nich, poziom statusu społeczno-ekonomicznego, ujemnie korelowała z liczbą leczonych pacjentów przypadających na jednego pediatrę $(-26,845, \mathrm{p}=0,010)$. Druga, stopień urbanizacji, wykazywała nieistotną statystycznie dodatnią korelację z liczbą leczonych pacjentów $(3,946, \mathrm{p}=0,664)$. Wnioski: Przeprowadzone badania sugerują, że czynniki społeczno-ekonomiczne mogą wpływać na nierównomierny rozkład przestrzenny obciążenia pracą pediatrów w Polsce oraz powodować różnice między województwami w równym dostępie do lekarzy pediatrów. Badania te mogą zatem dostarczyć implikacji dla polityki i praktyki, a także prowadzić do lepszego zrozumienia problemu.

Słowa kluczowe: status społeczno-ekonomiczny; urbanizacja; pediatrzy; dostęp do opieki zdrowotnej; zróżnicowanie regionalne 